\title{
Las traducciones al chino de Don Quijote: la competencia extralingüística del traductor chino en la cultura religiosa occidental
}

\author{
Li MeI LiU LiU 劉莉美 \\ Universidad Complutense de Madrid \\ limeigomez@gmail.com
}

Recibido: 28 de diciembre de 2014

Aceptado: 15 de abril de 2015

\section{RESUMEN}

Este trabajo pretende analizar la competencia extralingüística del traductor en los culturemas religiosos mediante el estudio de cuatro traducciones al chino de Don Quijote. Se expondrán los casos seleccionados y las notas de edición que se incluyen por sus traductores, y de estos ejemplos se deducirán unas cuestiones que se supone el caballo de batalla para el traductor chino en la explicitación de los referentes culturales religiosos.

Palabras clave: traducción cultural; traducción al chino de Don Quijote.

The Chinese translation of Don Quijote: The extra-linguistic competence of Chinese translator in Western religious culture.

\begin{abstract}
This paper proposes a reflection on the extra-linguistic competence of the translator in religious culturemes by studying Chinese translations of Don Quijote. We will analyze some examples and the editing notes of the translators. And we will conclude the formation of the Chinese translator in the trans-cultural elements in texts about the Catholic Christian religion.
\end{abstract}

Keywords: Cultural translation, Chinese translation of Don Quijote.

Sumario: 1. Introducción. 2. La competencia extralingüística del traductor en los culturemas religiosos. 3. Breve reseña de algunas traducciones al chino de Don Quijote. 4. El análisis de los ejemplos seleccionados y las notas de edición. 5. Conclusión. 


\section{Introducción}

Una traducción es una comunicación intercultural, por consiguiente, es imprescindible para un traductor conocer además de las dos lenguas, las dos culturas. Pero se llega a hablar incluso de la intraducibilidad cultural al referirse al trasvase de los elementos culturales característicos: "cuando un rasgo situacional, funcionalmente relevante para el texto en LO no existe en la cultura de la que la LT es parte" (Catford 1965/1970: 164) ${ }^{1}$. Precisamente, hay unos rasgos culturales que están muy presentes en el texto de Don Quijote, pero funcionalmente poco relevantes para la cultura de un receptor chino. Se trata de la tradición cristiana y las referencias bíblicas como fuente de inspiración en la obra cervantina. Estos antecedentes religiosos, sean "alarde de ortodoxia sincero o fingido" como dice Américo Castro, son el objeto de estudio de este trabajo. Con ello se pretende averiguar la competencia cultural que debe tener un traductor chino, ya que esos componentes representativos no pertenecen al acervo cultural de las tradiciones orientales.

De hecho, Cervantes pone en boca del personaje Sansón las siguientes palabras: "Finalmente, la tal historia es del más gustoso y menos perjudicial entretenimiento que hasta agora se haya visto, porque en toda ella no se descubre ni por semejas una palabra deshonesta ni un pensamiento menos que católico" (Don Quijote II, cap.3). Dicho pensamiento católico tradicional es lo que se ha recopilado en este trabajo: unos ejemplos con referencias a escritos religiosos que aisladamente se intercalan en los diversos capítulos de Don Quijote; con el fin de poder concluir la formación del traductor cuando se enfrenta a aspectos culturales sumamente arduos como es el ambiente religioso de la época cervantina que intentamos reseñar a continuación.

Antes de comenzar nuestro análisis sobre la competencia cultural del traductor chino, conviene valorar el ambiente que rodeó la aparición de Don Quijote, que es el período de los siglos XVI y XVII en el que su autor, Cervantes (1547-1616), vivió. Durante su época, la inquietud espiritual renacentista originó en España varias tendencias o actitudes heterodoxas: una de ellas reformista, paralela al movimiento protestante europeo mientras que España seguía siendo católica; y la otra de los erasmistas. El humanista Erasmo de Rotterdam (1466-1536) ejerció considerable influencia en el pensamiento religioso español, inclinando a algunos escritores hacia el protestantismo, aunque finalmente la política de la Contrarreforma terminó con este movimiento en España.

\section{La competencia extralingüística del traductor en los culturemas religiosos}

El eminente maestro Nida señala que para que una traducción alcance el éxito es más importante el dominio de las dos culturas que el de las dos lenguas, pues las palabras solo adquieren sentido en términos de las culturas en las que funcio-

${ }^{1}$ Cita tomada de Hurtado Albir, A., 2001, p.607.

${ }^{2}$ Castro, A., pensamiento de Cervantes. Ed. Noguer, S.A., 1925. 
$\operatorname{nan}^{3}$ (Nida 2001: 82). Y los elementos característicos de cada cultura son los culturemas, que se refieren a "un fenómeno social de una cultura $\mathrm{X}$ que es entendido como relevante por los miembros de esa cultura y que, comparado con un fenómeno correspondiente de una cultura $\mathrm{Y}$, es percibido como específico de la cultura X" (Nord 1997: 34)

Ya hemos mencionado antes que el ambiente religioso ocupa un lugar central en la estructura ideológica de la obra cervantina, de la que se hace eco en sus diversos episodios. Por ello, para conocer la competencia extralingüística del traductor chino en interpretar estos culturemas impregnados de referencias bíblicas y teológicas, que son ajenos a su propia cultura, hemos numerado en el siguiente apartado catorce ejemplos junto con las notas de edición de sus traductores. El uso de nota a pie de página es el método que se emplea para resolver los culturemas. Según Nida, las notas a pie de página de un texto traducido tienen dos funciones esenciales:

1) Corregir las discrepancias lingüísticas y culturales, por ejemplo, a) explicar las costumbres contradictorias; b) identificar objetos desconocidos geográficos o físicos; c) dar equivalentes de pesos y medidas; d) proporcionar información sobre juegos de palabras, y e) incluir datos suplementarios sobre nombres propios (...) 2) Añadir información que puede ser generalmente útil para comprender los antecedentes históricos y culturales del documento en cuestión. (Nida 2012: 256)

Por lo tanto, analizaremos a continuación si los traductores cumplen las funciones citadas por Nida con sus notas de edición.

\section{Breve reseña de algunas traducciones al chino de Don Quijote}

La variedad de traducciones, a razón de su popularidad, convirtió a Don Quijote en uno de los libros más editados del mundo, tal como Cervantes había presagiado ya con sus palabras "los niños la manosean, los mozos la leen, los hombres la entienden y los viejos la celebran; y, finalmente, es tan trillada y tan leída y tan sabida de todo género de gentes,..." (II, Cap. 3). Hoy en día ya se puede acceder fácilmente a distintas traducciones en chino. Entre los traductores de Don Quijote más conocidos, podríamos citar a Yang Jiang (libro editado por Literatura del Pueblo en 1978 y traducido desde la edición española de Francisco Rodríguez Marín de $1952^{5}$ ); Tu Mengchao (por la editorial Yilin de Nanjing en 1995 y traducido desde la edición española de Alhambra de 1988); Dong Yansheng (por la editorial de Literatura y Arte de Zhejiang en 1995 y traducido desde una edición española de 1984); Sun Jiameng (por la editorial Literatura y Arte de Octubre de Beijing en 2001 y traducido desde la edición de Planeta de 1994); Chui Weiben (Beijing, editorial Zhong-

\footnotetext{
3 "For truly successful translating biculturalism is even more important tan bilingualism, since words only have meanings in etrms of cultures in which they function".

4 Cita tomada de (Hurtado Albir 2001: 611).

5 El ingenioso hidalgo Don Quijote de la Mancha. Madrid: Espasa-Calpe, 1952.
} 
guo shaonian ertong en 2007). Este último se tradujo según la edición del Instituto Cervantes de 2004, dirigida por Francisco Rico.

Para realizar este trabajo se han consultado cuatro traducciones de las citadas anteriormente. Las abreviaturas que hemos utilizado para diferenciarlas son las siguientes: T1 (traducido por Yang Jiang: edición de 1992), T2 (por Sun Jiameng: 2001), T3 (por Dong Yangsheng: 2006) y T4 (por Chui Weiben: 2007).

\section{El análisis de los ejemplos seleccionados y las notas de edición}

En este apartado, pondremos principalmente de relieve las traducciones del T4, ya que se basan en la edición de un estudio completo y filológico que realizó el Instituto Cervantes en el año 2004; y al mismo tiempo contrastaremos las otras traducciones, citadas anteriormente, consideradas prestigiosas hasta hoy en día. Los ejemplos están configurados en tres columnas y tienen la disposición siguiente:

\begin{tabular}{|c|c|c|}
\hline $\begin{array}{c}\text { Texto recogido de Don Quijote y } \\
\text { notas de edición del CVC }\end{array}$ & $\begin{array}{c}\text { Traducciones al chino y sus notas } \\
\text { de edición }\end{array}$ & Traducciones mías al español \\
\hline $\begin{array}{l}\text { Ejemplo 1: } \\
\text { En lo que toca al poner anotaciones } \\
\text { al fin del libro, seguramente lo } \\
\text { podéis hacer desta manera: si } \\
\text { nombráis algún gigante en vuestro } \\
\text { libro, hacelde que sea el gigante } \\
\text { Golías, y con solo esto, que os } \\
\text { costará casi nada, tenéis una grande } \\
\text { anotación, pues podéis poner: «El } \\
\text { gigante Golías, o Goliat, fue un } \\
\text { fílisteo a quien el pastor David mató } \\
\text { de una gran pedrada, en el valle de } \\
\text { Terebinto, según se cuenta en el } \\
\text { libro de los Reyes...», en el capítulo } \\
\text { que vos halláredes que se escribe }{ }^{64} \text {. } \\
\text { (Nota de edición: (64) I Reyes, } \\
\text { XVII, 12-54, en la división antigua } \\
\text { de la Vulgata, que en la moderna } \\
\text { corresponden al mismo capítulo y } \\
\text { versículos de I Samuel). (I, Prólogo) }\end{array}$ & $\begin{array}{l}\text { T1 (I, prólogo) Nota de edición: } \\
\text { 見《舊約》 《撒母耳記上》十七 } \\
\text { 章。 } \\
\text { T2 (I, prólogo) Nota de edición: } \\
\text { 出自《圣经・撒母耳记》, (...) } \\
\text { T3 (I, prólogo) Nota de edición: } \\
\text { 出处应为《圣经 - 撒母耳记》。 } \\
\text { T4 (I, p. 11) Nota de edición: 《旧 } \\
\text { 约圣经》的一部分, 分上下两 } \\
\text { 卷, 记述公元前10至公元前6世纪 } \\
\text { 以色列民族的历史, 从所罗门王 } \\
\text { 称王讲起, 一直讲到耶路撒冷被 } \\
\text { 毁和以色列人被掳往巴比伦。 }\end{array}$ & $\begin{array}{l}\text { T1: Véanse el cap. } 17 \text { del I Samuel } \\
\text { del Antiguo Testamento. } \\
\text { T2: Proviene del libro de Samuel de } \\
\text { La Biblia. } \\
\text { T3: Aquí debe ser el libro de Samuel } \\
\text { de La Biblia. } \\
\text { T4: Es una parte del Antiguo } \\
\text { Testamento, que se divide en dos } \\
\text { tomos y narra la historia del pueblo } \\
\text { de Israel, desde el siglo X a.C. hasta } \\
\text { el siglo VI a.C., partiendo del } \\
\text { reinado de Salomón hasta la } \\
\text { destrucción de Jerusalén y la } \\
\text { cautividad de los israelitas en } \\
\text { Babilonia. }\end{array}$ \\
\hline
\end{tabular}

${ }^{6}$ El texto en chino del traductor T1 se transcribe en chino tradicional por la edición consultada y el resto en chino simplificado. Se encierra la parte de texto entre comillas cuando se trata de traducciones al chino del texto original español; si no, que pertenece a notas de edición de los traductores chinos. 


\begin{tabular}{|c|c|c|}
\hline $\begin{array}{l}\text { Ejemplo 2: } \\
\text { Encomendados sean a Satanás y a } \\
\text { Barrabás tales libros, que así han } \\
\text { echado a perder el más delicado } \\
\text { entendimiento que había en toda la } \\
\text { Mancha. (I, Cap. 5) }\end{array}$ & $\begin{array}{l}\mathrm{T} 1 \text { (I, p. 37) “我真恨不得一股腦 } \\
\text { 兒都交給地獄裡的魔鬼去! ” } \\
\mathrm{T} 2 \text { (I, p. 48) “快让这些书见鬼 } \\
\text { 去吧！” } \\
\text { T3 (I, p. 30) “真该把这些书扔到 } \\
\text { 地狱去见鬼！” } \\
\text { T4 (I, p. 63) “让这些书见鬼去 } \\
\text { 吧！” }\end{array}$ & $\begin{array}{l}\text { T1:¡Que se entreguen enteramente } \\
\text { al diablo del infierno! } \\
\text { T2: ¡Que estos libros se vayan a ver } \\
\text { al demonio! } \\
\text { T3: ¡Hay que tirar estos libros al } \\
\text { infierno para que vean al demonio! } \\
\text { T4: ¡Váyanse estos libros a ver al } \\
\text { demonio! }\end{array}$ \\
\hline $\begin{array}{l}\text { Ejemplo 3: } \\
\text {-Pues no tengas pena, amigo - } \\
\text { respondió don Quijote-, que yo te } \\
\text { sacaré de las manos de los } \\
\text { caldeos } \underline{\text { L }} \text {, cuanto más de las de la } \\
\text { Hermandad.(I, Cap. X) } \\
\text { (Nota de edición 12) "yo te sacaré } \\
\text { de apuros". Se trata de una alusión } \\
\text { bíblica, que puede remitir a varios } \\
\text { pasajes de Jeremías (XXXII, 28; } \\
\text { XLIII, 3; L, 8,etc.); caldeos es, } \\
\text { algunas veces, sinónimo de "magos, } \\
\text { encantadores". }\end{array}$ & $\begin{array}{l}\text { T1 (p. 76) Nota de edición: } \\
\text { 迦勒底亞爲巴比倫的一部分。紀 } \\
\text { 元前五三六年猶太人被迦勒底亞 } \\
\text { 人俘虜, 作了七十年奴隸, 波斯 } \\
\text { 王居魯士征服了這個國, 才把唒 } \\
\text { 太人釋放。 } \\
\text { T2 (p. 76) Nota de edición: } \\
\text { 加勒底, 古巴比伦的一个地区。 } \\
\text { T3 (I, p. 57) Nota de edición: } \\
\text { 迦勒底人, 古代巴比伦某个地区 } \\
\text { 的居民, 曾经征服过犹太人。 } \\
\text { T4 (p. 102) Nota de edición: } \\
\text { 此话出自圣经《先知书》, (...) }\end{array}$ & $\begin{array}{l}\text { T1: Caldea es una parte de Babilonia. } \\
\text { Los judíos, capturados por los caldeos } \\
\text { en el año } 536 \text { a.C., fueron prisioneros } \\
\text { durante } 70 \text { años hasta que el rey persa } \\
\text { Ciro conquistó este reino y liberó a los } \\
\text { judíos. } \\
\text { T2: Caldea es una zona de } \\
\text { Babilonia. } \\
\text { T3: Los caldeos eran habitantes de } \\
\text { una zona de Babilonia y habían } \\
\text { conquistado a los judíos. } \\
\text { T4: Esta frase proviene de la Biblia } \\
\text { Libro de profetas. }\end{array}$ \\
\hline $\begin{array}{l}\text { Ejemplo 4: } \\
\text { Mas, con todo esto, sube en tu } \\
\text { jumento, Sancho el bueno, y vente } \\
\text { tras mí, que Dios, que es proveedor } \\
\text { de todas las cosas, ...pues no falta a } \\
\text { los mosquitos del aire ni a los } \\
\text { gusanillos de la tierra ni a los } \\
\text { renacuajos del agua, y es tan } \\
\text { piadoso, que hace salir su sol sobre } \\
\text { los buenos y los malos y llueve } \\
\text { sobre los injustos y justos }{ }^{23} \text {. (I, Cap. } \\
\text { XVIII) } \\
\text { (Nota de edición 93) El párrafo } \\
\text { procede del Evangelio de Mateo. }\end{array}$ & $\begin{array}{l}\text { T1 (p.165) sin nota de edición. } \\
\text { T2 (I, p,133) sin nota de edición. } \\
\text { T3 (I, p. 116) sin nota de edición. } \\
\text { T4 (p.183) sin nota de edición. }\end{array}$ & \\
\hline
\end{tabular}




\begin{tabular}{|c|c|c|}
\hline $\begin{array}{l}\text { Ejemplo 5: } \\
\text { ¿Quién pudiera imaginar que don } \\
\text { Fernando, caballero ilustre, } \\
\text { discreto, obligado de mis } \\
\text { servicios, poderoso para alcanzar } \\
\text { lo que el deseo amoroso le pidiese } \\
\text { dondequiera que le ocupase, se } \\
\text { había de enconar, como suele } \\
\text { decirse, en tomarme a mí una sola } \\
\text { oveja que aún no poseía }{ }^{43} \text { ? (I, } \\
\text { Cap.XXVII) } \\
\text { (Nota de edición 43) Se alude a la } \\
\text { parábola con que Natán reprocha a } \\
\text { David su adulterio y homicidio. }\end{array}$ & $\begin{array}{l}\text { T1 (I, p. 284) Nota de edición: } \\
\text { 這是引用 《舊約全書》的典故。 } \\
\text { (...) } \\
\text { T2 (I, p. 204) sin nota de edición. } \\
\text { T3 (I, p. 194) sin nota de edición. } \\
\text { T4 (I, p. 292) Nota de edición: } \\
\text { 抢走羊羔的典故出自《旧约全书 } \\
》 。(\ldots)\end{array}$ & $\begin{array}{l}\text { T1: Es aquí una referencia bíblica } \\
\text { del Antiguo Testamento. (...) } \\
\text { T4: La referencia de "tomar una } \\
\text { oveja" proviene del Antiguo } \\
\text { Testamento. (...) }\end{array}$ \\
\hline $\begin{array}{l}\text { Ejemplo 6: } \\
\text { En fin, yo salí de aquella casa y } \\
\text { vine a la de aquel donde había } \\
\text { dejado la mula; hice que me la } \\
\text { ensillase, sin despedirme dél subí } \\
\text { en ella, y salí de la ciudad, sin } \\
\text { osar, como otro Lot, volver el } \\
\text { rostro a miralla } \underline{\text { XL, }} \underline{69} \text {; ...(I, Cap. } \\
\text { XXVII) } \\
\text { (Nota de edición 69) Los ángeles } \\
\text { mandaron salir a Lot de Sodoma } \\
\text { mientras esta era destruida, y le } \\
\text { ordenaron no volver la cabeza } \\
\text { para mirarla (Génesis, XIX, 17). }\end{array}$ & $\begin{array}{l}\text { T1 (I, p. 291) Nota de edición: } \\
\text { 這是引用《聖經》羅得典故。(..) } \\
\text { T2 (I, p. 208) Nota de edición: } \\
\text { 罗特, 《圣经》中的人物, (..) } \\
\text { T3 (I, p. 198) Nota de edición: } \\
\text { 罗得, 《圣经》人物。( (..) } \\
\text { T4 (I, p.299) Nota de edición: } \\
\text { 《圣经》创世纪篇中的故事。(..) }\end{array}$ & $\begin{array}{l}\text { T1: Es aquí una referencia bíblica } \\
\text { sobre Lot. (...) } \\
\text { T2: Lot es un personaje de La } \\
\text { Biblia, (...) } \\
\text { T3: Lot es un personaje de La } \\
\text { Biblia, (...) } \\
\text { T4: Historia que se encuentra en el } \\
\text { capítulo Génesis de La Bíblia. }\end{array}$ \\
\hline $\begin{array}{l}\text { Ejemplo } 7 \text { : } \\
\text { Y si todavía } 25 \text {, llevado de su } \\
\text { natural inclinación, quisiere leer } \\
\text { libros de hazañas y de caballerías, } \\
\text { lea en la Sacra Escritura el de los } \\
\text { Jueces }{ }^{26} \text {, que allí hallará verdades } \\
\text { grandiosas y hechos tan } \\
\text { verdaderos como valientes.Un } \\
\text { Viriato tuvo Lusitania; un César, } \\
\text { Roma; un Anibal, Cartago } \\
\text { http://cvc.cervantes.es/literatura/cl } \\
\text { asicos/quijote/edicion/parte1/cap4 } \\
\text { 9/cap49_02.htm - np28n; un } \\
\text { Alejandro, Grecia; un conde } \\
\text { Fernán González, Castilla; un Cid, } \\
\text { Valencia; (..http://cvc.cervantes.es/ } \\
\text { literatura/clasicos/quijote/edicion/ } \\
\text { parte1/cap49/cap49_02.htm } \\
\text { np32n.) (I, Cap.XLIX) } \\
\text { (Nota de edición 26) El Concilio } \\
\text { de Trento, y antes el índice de } \\
\text { Valdés para España, habían } \\
\text { prohibido la traducción y lectura } \\
\text { de la Biblia en lengua vulgar; no } \\
\text { se dice que Don Quijote supiese } \\
\text { leer latín. }\end{array}$ & $\begin{array}{l}\text { T1 (I. p. 549) sin nota. } \\
\text { T2 (I, p. 373) “(...) 那就阅读《圣 } \\
\text { 经》中的《士师》讷。那里讲 } \\
\text { 的都是确對的实话, 真实的英雄 } \\
\text { 业绩 : 卢西塔尼亚出了个维里亚 } \\
\text { 托, (...)”. Sin nota. } \\
\text { T3 (I, p. 372) sin nota. } \\
\text { T4 (I, p. 544) sin nota. }\end{array}$ & $\begin{array}{l}\text { T2: “(...) lea entonces el libro de } \\
\text { Los Jueces de La Biblia. Allí se } \\
\text { hallarán verdades grandiosas y } \\
\text { hechos tan verdaderos como } \\
\text { valientes: un Viriato tuvo } \\
\text { Lusiania; un César, Roma; (...) }\end{array}$ \\
\hline
\end{tabular}




\begin{tabular}{|c|c|c|}
\hline 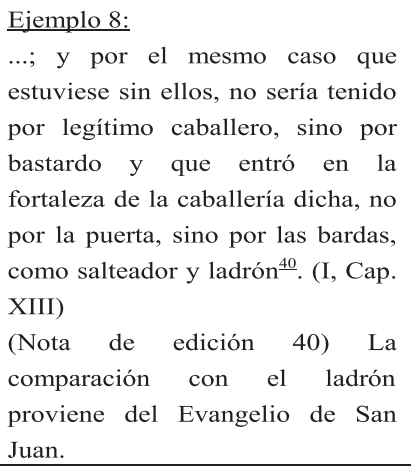 & $\begin{array}{l}\text { T1 (I, p. 104) sin nota } \\
\text { T2 (I, p. 93) sin nota. } \\
\text { T3 (I, p. 74) sin nota. } \\
\text { T4 (I, p. 126) sin nota. }\end{array}$ & \\
\hline $\begin{array}{l}\text { Ejemplo 9: } \\
\text { De mis viñas vengo, no sé nada, } \\
\text { no soy amigo de saber vidas } \\
\text { ajenas, que el que compra y } \\
\text { miente, en su bolsa lo siente. } \\
\text { Cuanto más, que desnudo nací, } \\
\text { desnudo me hallo: ni pierdo ni } \\
\text { gano }{ }^{13} \text {. (I, Cap. XXV) } \\
\text { (Nota de edición 13) Sancho } \\
\text { vuelve a repetir ese refrán de } \\
\text { reminiscencias bíblicas varias } \\
\text { veces en la Segunda parte (II, } 8 \text {, } \\
689 \text {; 53, 1065; 55, 1082, y } 57 \text {, } \\
1090 \text { ). }\end{array}$ & $\begin{array}{l}\text { T1 (I, p.246) Nota de edición: } \\
\text { 西班牙浐语 } \\
\text { T2 (I, p.182) sin nota. } \\
\text { T3 (I, p.172) sin nota. } \\
\text { T4 (I, p.258) sin nota. }\end{array}$ & T1: "Se trata de un refrán español" \\
\hline $\begin{array}{l}\text { Ejemplo } 10 \text { : } \\
\text {-Los gentiles -respondió don } \\
\text { Quijote- sin duda están en el } \\
\text { infierno; los cristianos, si fueron } \\
\text { buenos cristianos, o están en el } \\
\text { purgatorio, o en el cielo }{ }^{47} \text {. (II, } \\
\text { CAP. VIII) } \\
\text { (Nota de edición 47) Alude al } \\
\text { debatido tema de la eventual } \\
\text { salvación de los paganos. }\end{array}$ & $\begin{array}{l}\text { T1 (II, p. 67) sin nota. } \\
\text { T2 (II, p. 449) sin nota. } \\
\text { T3 (II, p. 448) sin nota. } \\
\text { T4 (II, p. 78) sin nota. }\end{array}$ & \\
\hline $\begin{array}{l}\text { Ejemplo 11: } \\
\text {-Está bien -dijo Sancho-, pero } \\
\text { sepamos ahora: esas sepulturas } \\
\text { donde están los cuerpos } \\
\text { desosseñorazos ¿tienen delante de } \\
\text { sí lámparas de plata, o están } \\
\text { adornadas las paredes de sus } \\
\text { capillas de muletas, de mortajas, } \\
\text { de cabelleras, de piernas y de ojos } \\
\text { de cera }{ }^{48} \text { ? Y si desto no, ¿de qué } \\
\text { están adornadas? (II, C. VIII) } \\
\text { (Nota de edición 48) Los objetos } \\
\text { mencionados son exvotos en } \\
\text { agradecimiento por curaciones. }\end{array}$ & $\begin{array}{l}\text { T1 (II, p. 67) Nota de edición: } \\
\text { 当时西班牙人相信圣人的遗体或 } \\
\text { 遗物能产生奇迹, 例如使死人复 } \\
\text { 活(...) } \\
\text { T2 (II, p.450) sin nota. } \\
\text { T3 (II, p.78)(II, p.448) sin nota. } \\
\text { T4 Nota de Edición: 褂着这些 } \\
\text { 东西, 是病人求神显灵治好疾病 } \\
\text { 以后来挂的。如痏腿的治好了就 } \\
\text { 把原来的拐杖挂在教堂的墙上。 }\end{array}$ & $\begin{array}{l}\text { T1: Por aquel entonces, los } \\
\text { españoles creían que las reliquias } \\
\text { de un santo y sus pertenencias } \\
\text { podían hacer milagros, por } \\
\text { ejemplo: resucitar a los muertos, } \\
\text { (...) } \\
\text { T4: Los objetos nombrados se } \\
\text { suelen colgar en las paredes de las } \\
\text { iglesias cristianas; los llevan los } \\
\text { enfermos que han sido sanados } \\
\text { después de habérselo pedido a } \\
\text { Dios. Por ejemplo, los cojos } \\
\text { cuelgan las muletas que usaban en } \\
\text { la pared de iglesia".) }\end{array}$ \\
\hline
\end{tabular}




\begin{tabular}{|c|c|c|}
\hline $\begin{array}{l}\text { Ejemplo 12: } \\
\text { Llegó Sancho, y como vio el } \\
\text { rostro del bachiller Carrasco, } \\
\text { comenzó a hacerse mil cruces y a } \\
\text { santiguarse otras tantas }{ }^{72} \text {. En todo } \\
\text { esto no daba muestras de estar } \\
\text { vivo el derribado caballero,... (II } \\
\text { Cap. 14) } \\
\text { (Nota de edición } 72 \text { ) 'asombrarse } \\
\text { ante lo absolutamente inesperado', } \\
\text { además de su sentido recto. }\end{array}$ & $\begin{array}{l}\text { T1 (II, p. 120) Nota de edición: } \\
\text { 據天主教的迷信, 這是鎮邪驅鬼 } \\
\text { 的。 } \\
\text { T2 (II, p. 484)Sin nota. } \\
\text { T3 (II, p. 481) sin nota. } \\
\text { T4 (II, p. 127) sin nota. }\end{array}$ & $\begin{array}{l}\text { T1: Según la superstición católica, } \\
\text { sirve para ahuyentar el espíritu } \\
\text { diabólico. }\end{array}$ \\
\hline $\begin{array}{l}\text { Ejemplo 13: } \\
\text { Atentísimo estuvo Sancho a la } \\
\text { relación de la vida y } \\
\text { entretenimientos del hidalgo, y, } \\
\text { pareciéndole buena y santa y que } \\
\text { quien la hacía debía de hacer } \\
\text { milagros, se arrojó del rucio y con } \\
\text { gran priesa le fue a asir del estribo } \\
\text { derecho, y con devoto corazón y } \\
\text { casi lágrimas le besó los pies una } \\
\text { y muchas veces. (II, Cap. 16) }\end{array}$ & $\begin{array}{l}\text { T1 (II, p. 132) Nota de edición: } \\
\text { 中世紀天主教的迷信, } \\
\text { 以為成了怪人就能創造奇蹟。 } \\
\text { T2 (II, p. 491) sin nota. } \\
\text { T3 (II, p. 89) sin nota. } \\
\text { T4 (II, p. 137) sin nota. }\end{array}$ & $\begin{array}{l}\text { T1: La superstición católica } \\
\text { medieval considera que un } \\
\text { individuoal convertirse en una } \\
\text { persona extraña puede hacer } \\
\text { milagros. }\end{array}$ \\
\hline $\begin{array}{l}\text { Ejemplo 14: } \\
\text {-Este sí que es caballero, y de las } \\
\text { escuadras de Cristo: este se llama } \\
\text { don San Diego Matamoros } \frac{18}{} \text {, uno } \\
\text { de los más valientes santos y } \\
\text { caballeros que tuvo el mundo y } \\
\text { tiene agora el cielo. (II, Cap. 58) } \\
\text { (Nota de edición 18) 'Santiago a } \\
\text { caballo con la espada levantada y } \\
\text { un moro a los pies del animal', tal } \\
\text { como se le representa por su } \\
\text { supuesta actuación en la batalla de } \\
\text { Clavijo. Diego, Jaime, Jacobo y } \\
\text { Santiago son formas del mismo } \\
\text { nombre. }\end{array}$ & $\begin{array}{l}\text { T1 (II, p. 516) “不用說, } \\
\text { 這也是基督教隊伍裡的騎士, 叫 } \\
\text { 作摩爾人的繁星、堂聖狄艾果”. } \\
\text { Nota de edición: 聖狄艾果 (San Diego) } \\
\text { 即聖悌亞果 } \\
\text { (Santiago), 亦即聖雅各 (San } \\
\text { Jacobo 或 San Jaime) 他和他弟 } \\
\text { 弟約翰同是耶穌的門徒。他被希 } \\
\text { 律王殺害, 傳說他在巴勒斯坦遇 } \\
\text { 害後, 遺體由無人駕駛的航船送 } \\
\text { 到西班牙海岸。西班牙人把它當 } \\
\text { 作護國神。 } \\
\text { T2 (II, p. 726) Nota de edición: } \\
\text { “迭哥, 即圣地亚哥, 耶稣十二 } \\
\text { 使徒之一, 死于公元44年。 } \\
\text { T3 (II, p. 744) sin nota de edición. } \\
\text { T4 (II, p. 478) Nota de edición: 即 } \\
\text { 圣地亚哥, 耶稣十二使徒之一。 } \\
\text { 据说奉耶稣之名到西班牙传教, } \\
\text { 殉教后埋葬在西班牙。还船说在 } \\
\text { 西班牙光复战争中曾帮助西班牙 } \\
\text { 军队占胜摩尔人。 }\end{array}$ & $\begin{array}{l}\text { T1: No hace falta que digamos que } \\
\text { este también es el caballero de las } \\
\text { escuadras de Jidujiao, llamado don } \\
\text { San Diego Matamoros, (...). Nota } \\
\text { de edición: San Diego es Santiago, } \\
\text { también San Jacobo o San Jaime. } \\
\text { Junto con su hermano Juan eran } \\
\text { discípulos de Jesús. Se dice que el } \\
\text { rey Herodes le asesinó y, después } \\
\text { de su muerte en Pakistán, un barco } \\
\text { sin timonel llevó su cadáver hasta } \\
\text { la costa de España. Los españoles } \\
\text { lo toman como patrón nacional. } \\
\text { T2: Diego es Santiago, uno de los } \\
\text { doce discípulos de Jesús, y murió } \\
\text { en el año } 44 . \\
\text { T4: Se trata de Santiago, uno de } \\
\text { los doce discípulos de Jesús. Se } \\
\text { dice que siguiendo las órdenes de } \\
\text { Jesús, llegó a España para predicar } \\
\text { el evangelio. Murió y fue } \\
\text { enterrado en este país como mártir. } \\
\text { También se dice que en las guerras } \\
\text { de Reconquista ayudó al ejército } \\
\text { español a vencer a los } \\
\text { musulmanes. }\end{array}$ \\
\hline
\end{tabular}




\section{Comentario del ejemplo 1:}

¿Cuáles fueron las versiones bíblicas, impresas o manuscritas, que Cervantes manejó? En tiempo de los Reyes Católicos, los judíos fueron expulsados de España y estaban prohibidas traducciones de las Sagrada Escrituras a la lengua vulgar, por lo que se impuso como texto único la Vulgata latina. Las notas de T1 y T3 señalan correctamente el libro de Samuel (Primero, Cap.17: 12-54) donde se describe la historia de David y Goliat. Sin embargo, la nota del T4 es errónea ya que hace referencia al "libro de los Reyes" como es la división antigua de la Vulgata; pues el pasaje bíblico sobre el gigante Goliat aparece hoy en día en el Libro de Samuel, siguiendo la nomenclatura hebrea, de las traducciones posteriores de la Biblia. Por lo tanto, la explicación del traductor T4 apunta equivocadamente al Primer y Segundo libro de los Reyes de las traducciones posteriores de la Biblia, en ellos no se relata la historia de Goliat. En cuanto a la nota del T3, no se explica la razón por la que debe ser el libro de Samuel, lo que puede confundir al lector chino, pues podría entender que se trata de un posible error del autor de Don Quijote.

\section{Comentario del ejemplo 2:}

Las palabras "encomendados a Satanás y Barrabás..." son del ama de llaves de Don Quijote, pues le molestaba la pasión que sentía su amo por las novelas de caballerías. Podemos entender que esta expresión del ama de llaves muestra su ignorancia respecto a la figura de Barrabás, pues la pone a la misma altura de Satanás por falta de conocimientos bíblicos. Aquí los 4 traductores han empleado el mismo procedimiento técnico que consiste en simplificar los dos elementos con cargas religiosas: "Satanás y Barrabás", pues ninguna de estas traducciones al chino recoge al personaje bíblico Barrabás sino que lo asimila a Satanás (el diablo).

\section{Comentario del ejemplo 3:}

Por un lado, Caldea en realidad no es una parte de Babilonia, pues pertenece a la zona del Éufrates y el Tigris en Mesopotamia. Aunque se confundió en un tiempo con toda la región de Babilonia, geográficamente no es así. Por lo tanto, las notas de T1 y T2 resultan ambiguas. Además, el traductor T2 no informa de la rivalidad que había entre los caldeos y los judíos. Por otro lado, la nota en chino del T4 señala: "estas palabras provienen del Libro de profetas", sin embargo, el libro de Jeremías pertenece a uno de los muchos libros proféticos del Antiguo Testamento. No existe el Libro de profetas, sino los libros proféticos (que son 18 según la Biblia de Jerusalén). Aquí nos encontramos con un ejemplo donde los dos traductores simplifican la información bíblica.

\section{Comentario del ejemplo 4:}

Ninguno de los traductores chinos hace referencia a la cita bíblica. Esta información sí se encuentra en la nota de edición española y se supone que el T4 debe- 
ría reflejarla tal como otras notas del traductor sobre las referencias bíblicas. Por lo tanto, este ejemplo demuestra que hay una falta de coherencia a la hora de explicitar las citas o alusiones bíblicas.

\section{Comentario del ejemplo 5:}

El T4 abrevia la nota 43 de la edición del Instituto Cervantes, indicando que su fuente proviene del Antiguo Testamento, sin precisar ni el libro concreto $\left(2^{\circ}\right.$ de Samuel) ni los capítulos (cap. 11 y 12) como en otros casos (por ejemplo: Tomo I, notas 1 de p.515 y de p.521). El Antiguo Testamento son en total 46 libros según la Biblia de Jerusalén. Así, vemos aquí otro ejemplo de la falta de uniformidad con la redacción de las notas de edición. Mientras que los dos traductores T1 y T4 extienden sus comentarios sobre la historia de Natán y David, pues la considerarían sugerente para los lectores chinos.

\section{Comentario del ejemplo 6:}

En este caso, el T4 omite la nota de edición española del Instituto Cervantes que sí precisa el origen del "Génesis, XIX, 17". Además, nos hace dudar si el traductor entiende que el libro de Génesis es un capítulo de la Biblia, pues, en su nota “《圣经》创世纪篇”, el signo de puntuación《》, que sirve para encerrar el título de los libros, solo se aplica a la palabra 圣经 (la Biblia) y no incluye la palabra 创世纪 (el Génesis). Aquí puede tratarse de un posible descuido del traductor.

\section{Comentario del ejemplo 7:}

Aquí, el traductor T2 utiliza el signo de puntuación "dos puntos" antes de los personajes citados, el lector chino puede malinterpretar que se trata de figuras bíblicas. Por otra parte, no se sabe la razón por la que el T4 ha optado por ignorar la nota de edición española, el receptor chino pierde una información relevante sobre la prohibición de traducir la Biblia en lengua vulgar en aquel entonces. En este caso, se podría considerar una frase de Cervantes con cierta connotación "polémica", puesto que se debía tener conocimiento de latín para poder leer la Biblia.

Comentario de los ejemplos 8,9 y 10 :

Ninguno de los cuatro traductores ha detectado las alusiones bíblicas en los ejemplos 8 y 9 . En el caso del 10, un receptor chino tampoco recibe la misma información en la traducción del T4 que se recoge en la nota de edición española.

\section{Comentario del ejemplo11:}

Por un lado, el T1 incurre en su modo de generalización anotando que "por aquel entonces, los españoles creían que...". Por otro lado, el T4 emplea la denominación “基督教”, que en chino no significa exclusivamente "las iglesias católicas” sino que 
incluye también las confesiones protestantes o evangélicas. Estas no colocan exvotos pues lo consideran una práctica contraria a los principios de la Reforma Protestante. Además, el traductor T4 omite que los exvotos se colocan junto a las imágenes de Dios, la Virgen o los santos al que se ha hecho la petición, así lo comenta el diccionario de la RAE: “(...) los fieles dedican a Dios, a la Virgen o a los santos en señal y recuerdo de un beneficio recibido, y que se cuelgan en los muros o en la techumbre de los templos".

Comentario de los ejemplos 12 y 13 :

Aquí el traductor T1 ha emitido un juicio subjetivo y generalizado en los dos ejemplos al afirmar que esto ocurre "según las supersticiones católicas" nión, el traductor debería mantener una postura neutra. Además, tanto el traductor T1 como el traductor T4, ambos omiten la segunda parte del texto original del ejemplo 12: "a santiguarse otras tantas" (el traductor T4 suprime la nota de edición). Por lo que podemos observar que los traductores han unificado los términos de la frase "hacerse cruces" y "santiguarse".

\section{Comentario del ejemplo 14:}

Para traducir la palabra "Cristo", el traductor T1 utiliza el término mencionado “基督教”, que en chino se refiere exclusivamente a las iglesias evangélicas u otras denominaciones que difieren de las católicas (en chino 天主教 Tianzhujiao). Pero su nota de edición apunta evidentemente a las tradiciones de las iglesias católicas a pesar de que no explicita su fuente de información. En cuanto a la nota explicativa del traductor T4, no se encuentra ningún pasaje bíblico donde se mencione literalmente que Jesús envió a Santiago a España para predicar el evangelio. Aquí también se trata de tradiciones católicas y el traductor tampoco aporta, en este caso, el origen de esta información. El traductor no informa que el dogma católico está constituido por la Biblia, las Tradiciones y el Magisterio.

\section{Conclusión}

En definitiva, podemos concluir con las siguientes reflexiones a través de los ejemplos analizados: en primer lugar, hay una falta de coherencia a la hora de explicitar las citas o referencias bíblicas. En el caso del T4, se puede cuestionar cuáles son los criterios del traductor para llevar a cabo sus decisiones de prescindir o para-

\footnotetext{
${ }^{7}$ Respecto al tema de santiguarse en el mundo católico, en realidad no es o no debe entenderse como una superstición. Esta práctica no pertenece a ninguna teología cristiana ni a la experiencia de un creyente católico consecuente con sus creencias. Para él el santiguarse es una forma de expresar la fe en el Dios trinitario (en el nombre del Padre, del Hijo y del Espíritu Santo). El gesto pertenece a la pedagogía o la catequética, que trata de hacerlo más "visible" y fácil de recordar cuando a la palabra que se dice le acompaña un gesto.
} 
frasear las notas de la edición española. Tal como el propio traductor manifiesta en el apéndice de su edición en chino (p. 606): "ya que las notas de edición (del CVC) no son suficientes para los lectores chinos ni para la necesidad de los traductores chinos, hay que solventar algunas dudas que no se plantearían para un lector español", nos surgen preguntas como las siguientes: ¿por qué razón el traductor omite muchas veces notas de edición que se han aportado al receptor español? (Véanse los ejemplos 6, 7, 8 y 9); ¿qué tipo de información el traductor considera que carece de importancia para un lector oriental?; ¿hasta qué punto el traductor puede ser "visible" o libre para determinar el derecho de saber de su receptor? y ¿cuáles son los criterios apropiados para suprimir o añadir más información que la edición de donde procede?

En segundo lugar, se percibe también la falta de neutralidad en algunas notas del traductor: por ejemplo, el traductor T1 está condicionado ideológicamente a su adición de información (véanse ejemplos 12 y 13). Este tipo de inclinaciones ideológicas puede desorientar a los lectores de la lengua meta. Vidal Claramonte afirma que "Traducir ya no es, ni mucho menos, un acto inocente, (...), puede alterar el canon de una cultura o la imagen que se tiene de otra sociedad ${ }^{8}$.

Por último, podemos señalar también la falta de competencia de los culturemas religiosos por parte de los traductores por no poder reflejar íntegramente la inquietud espiritual o la preocupación por los temas religiosos del autor de Don Quijote. Las tradiciones cristianas junto a la mitología grecolatina son las dos fuentes principales de las múltiples expresiones culturales en la civilización occidental, y por ello son conocimientos necesarios para la formación de un traductor chino, especialmente cuando se trata de una obra cumbre de las letras española como es Don Quijote.

\section{Referencias bibliográficas}

Castro, A., El pensamiento de Cervantes. Madrid: Ed. Noguer, S.A., 1925.

CAtFord, J. C., A linguistic Theory of Translation: An Essay in Applied Linguistics, Londres: Oxford University Press, 1965 (Una teoría lingüistica de la traducción: ensayo de lingüistica aplicada. Carasca: Universidad Central de Venezuela, 1970.)

CHEN, Chia-ying, Estudio sobre la traducción al chino de los refranes de Sancho Panza en Don Quijote de Yang Chiang. Tesina de Máster de la Universidad Providence de Taiwan, 2009.

Hurtado Albir, A., Traducción y traductología. Madrid: Cátedra, 2001.

NidA, E.A., Sobre la traducción. Madrid: Cátedra, 2012.

NiDA, E.A., Language and Culture-Contexts in Translating, Shanghai: shanghai foreign language education press: 2001.

NorD, Ch., Translating as a Purposeful Activity. Functionalist Approaches Explained, Manchester: St. Jerome Publishing, 1997.

- Don Quijote de la Mancha. Edición del Instituto Cervantes, dirigida por Francisco Rico (http://cvc.cervantes.es/literatura/clasicos/quijote/ Fecha de consulta: 6 de enero de 2015

${ }^{8}$ Cita tomada de Hurtado Albir, A,. Traducción y traductología. Madrid: Cátedra, 2001, p. 617. 
Ediciones en chino consultadas de Don Quijote:

楊絳(Yang Jiang) 译, 《堂吉軻德》台北: 聯經, 1992.

孙家孟(Sun Jianmeng)译, 《奇想联翩的绅士堂吉诃德・德・拉曼恰》北京: 北京十月 文艺出版社, 2001.

董燕生(Dong Yansheng) 译, 《奇思异想的绅士堂吉诃德 - 德 - 拉曼却》武汉: 长江文 艺出版社, 2006.

崔维本(Chui Weiben) 译, 《堂吉诃德》北京: 中国少年儿童, 2007. 